\title{
A BIM-Based Study on the Comprehensive Benefit Analysis for Prefabricated Building Projects in China
}

\author{
Yingbo Ji, ${ }^{1}$ Siwei Chang $\mathbb{D}^{1},{ }^{1}$ Yuan Qi, ${ }^{1}$ Yan $\mathrm{Li}^{2}{ }^{2}$ Hong Xian Li $\mathbb{D},{ }^{2}$ and Kai Qi \\ ${ }^{1}$ School of Civil Engineering, North China University of Technology, Beijing 100043, China \\ ${ }^{2}$ School of Architecture and Built Environment, Deakin University, Geelong 3220, Australia \\ Correspondence should be addressed to Siwei Chang; siwei_chang@126.com
}

Received 27 January 2019; Revised 22 March 2019; Accepted 2 April 2019; Published 2 May 2019

Guest Editor: Eugenio Pellicer

Copyright (c) 2019 Yingbo Ji et al. This is an open access article distributed under the Creative Commons Attribution License, which permits unrestricted use, distribution, and reproduction in any medium, provided the original work is properly cited.

Prefabricated construction has been widely accepted as an alternative to conventional cast-in-situ construction, given its improved performance. Great efforts have also been made to develop prefabricated construction technologies in China. However, there is a lack of an appropriate pattern for evaluating its comprehensive economic merits, and reasonable mathematical models for providing a comparative analysis of conventional cast-in-situ and prefabricated building projects have yet to be developed. Therefore, the research in this paper aims to comprehensively evaluate the economic benefits of implementing prefabricated construction techniques in order to surpass the economic barrier and promote the development of prefabricated buildings in China. The comprehensive economic evaluation is formulated in terms of resource-use efficiencies, project progress, and incentive policies. An apartment building in Shanghai is selected as a case study. Construction progress is simulated on the BIM platform when the same case study is rationally transformed from the prefabricated to the conventional cast-in-situ construction technique. The results reveal that the comprehensive economic merit can reach $¥ 739.6 / \mathrm{m}^{2}$ when selecting the prefabricated construction process. The economic benefit brought by shortening the construction period can be regarded as the most significant contributor. Yet, the current incentive policies only contribute $7.1 \%$ of the comprehensive economic evaluation. Overall, this research contributes an assessment framework for decision-making in the technique management of building construction. The BIM-based simulation approach can greatly help investors to identify the relevant economic factors and adopt the latest incentive policies.

\section{Introduction}

The adoption of new technological advancement in the construction industry plays an important role in achieving project success. For example, prefabrication technology has been widely practiced in many countries and has fostered substantial change in the development of the construction industry worldwide in recent decades $[1,2]$. Prefabricated construction refers to the practice of designing and fabricating building elements in manufacturing factories, transporting the elements to construction sites, and assembling the elements to a greater degree of finish for rapid site assembly compared to traditional piecemeal on-site construction $[3,4]$. Since building elements can be selected to achieve automated production in factories and assembled on site through the semimanufacturing construction method, interchangeable terminologies associated with prefabricated construction in the existing literature include off-site prefabrication [5], off-site construction [6], and off-site manufacturing construction [7].

Prefabricated concrete construction can be regarded as a widely accepted alternative to conventional cast-in-situ concrete construction owing to numerous benefits for investors and contractors, such as safer construction environments, faster construction progresses, enhanced quality outputs, and less labour rework on-site [8-10]. Construction schedule can be significantly shortened as a large number of construction activities that can be automated and finished in manufacturing factories. The indoor built environment also contributes to improved construction safety, and construction activities with high health and safety risks can be effectively reduced or even avoided on construction sites [11]. In a factory-controlled environment, there is less risk for problems associated with moisture, environmental 
hazards, and dirt, and there are strict factory processes and procedures that protect workers from on-the-job injury [12-14]. As for environmental sustainability, prefabricated concrete construction offers benefits in waste reduction [15], facilitates the reuse of some components [16], and reduces water consumption [17]. Prefabricated building modules can also be designed and fabricated with requests of clients to meet living comfort requirements [18].

Based on the aforementioned merits, prefabricated buildings (PRBs) have also been greatly developed to meet the requirements of sustainability and housing demand in China [1]. China has also embarked on several initiatives to promote prefabrication [19]. For instance, the Ministry of Housing and Urban-Rural Development recently stated that China will strive to increase the proportion of PRBs to $30 \%$ of new building areas and increase the number of highly skilled industrial workers to 3 million within 10 years [20]. However, in comparison to traditional building (TRB) construction, there are also notable disadvantages that should be considered, such as transportation restrictions and span limits [21]. PRB projects also require increased and more detailed coordination at all stages, which increases the difficulty in progress monitoring and planning. From the economic perspective, prefabricated components incur more initial investment, higher taxes, and more incremental costs $[22,23]$.

\section{Literature Review}

Considering availability and selection of the construction techniques, the economic analysis of PRB projects should be conducted for projecting the potential expenditure and indicating their economic benefits. Recently, Jeong et al. [24] selected a case study in South Korea and evaluated several performance indices through the Web-CYCLONE simulation when replacing conventional steel-reinforced concrete columns with form-latticed prefabricated steel-reinforced concrete columns. The results found cost savings of $1.32 \%$. In 2017, Afzal et al. [25] proposed research involving the economic estimation and performance for both prefabricated and conventional construction techniques. Their study reported a sound cost performance of about 5.74 million PKR (Pakistani Rupee) when prefabrication was used for the construction of the given case study building project. However, some studies have expressed concerns regarding the practicability of prefabricated construction in terms of its economical effectiveness [26, 27]. For example, a perceived higher cost has been seen as one of the four main barriers in Australia's prefabricated construction [28]. In particular, material increment costs and labour costs are capable of producing significant impacts on the production cost [29]. In 2018, Hong et al. [1] investigated basic cost composition of prefabrication and examined the effects of adopting prefabrication on the total cost of building projects. Results suggested that transportation could account for $10 \%$ of the total cost and the average incremental cost was linearly correlated with the prefabrication rate, which ranged from $¥ 237 / \mathrm{m}^{2}$ to $¥ 437 / \mathrm{m}^{2}$ for the selected projects. The work of Mao et al. [23] also conducted an analysis on expenditure items of prefabricated and conventional construction methods through a case study approach in China. The research compared the civil project budget costs of a residential building designed in accordance with the PRB design and traditional design schemes based on bid documents and construction drawings, indicating that the PRB incremental cost could reach $¥ 32 / \mathrm{m}^{2}$.

Overall, economic benefits of implementing prefabricated construction techniques should be clarified. It is, therefore, necessary to comprehensively evaluate economic benefits from PRB projects in order to break the economic barrier and promote the development of PRBs in China. In particular, the potential economic effects produced by resource-use efficiencies, project progress, and incentive policies need to be further investigated in China's construction industry. Moreover, developing an appropriate pattern for obtaining accurate cost data and reasonable mathematical models for providing a comparative analysis of TRB and PRB projects are also challenges. In addressing these challenges, building information modelling (BIM), as a digital model-based process, emerges as a solution to rapidly simulate and identify the economic impacts of different construction techniques.

Building information modelling (BIM) is regarded as an engineering data platform that integrates various data from engineering projects based on three-dimensional (3D) digital technologies [30]. Refined 3D models can be used to correlate the schedule and cost information of the whole construction process through simulation [31, 32]. The automatic calculation tools of BIM platforms are also capable of effectively reducing error rates for the cost calculation results. In addition, BIM has been applied to prefabricated construction [33]. For example, in 2017, a new BIM-based $4 \mathrm{D}$ construction simulation framework was proposed by Lee and Kim [34] to explore the improved management method for modular construction projects. On the basis of the new framework, a visually optimal manufacturing process was identified from the perspectives of resources, material, and quality, and it was also verified that time and cost for module manufacturing could be reduced by the proposed framework. Furthermore, the work of Baltasi and Akbas [35] demonstrated a preconstruction cost analysis method using BIM and prototype resource integrated planning and simulation software, namely, GSimX, proving that the BIMbased cost estimation method was capable of rapidly and accurately producing economic results. The synergy of integrating BIM and prefabrication could also minimise unnecessary and costly rework and conserve resources [36].

Yet, relatively little research exists regarding the comprehensive economic evaluation by adopting BIM within the prefabrication industry, and few mathematical models considering possible economic values are caused by time and political factors. Thus, the research in this paper aims to propose a comparative analysis of $\mathrm{TRB}$ and $\mathrm{PRB}$ projects based on BIM simulation. PRB projects are rationally transformed into TRB projects through case study method on a BIM platform. The proposed mathematical models consider potential economic effects produced by resourceuse efficiencies, project progress, and incentive policies to 
conduct a comprehensive economic evaluation. The assessment measure can be beneficial for decision makers to consider appropriate construction techniques in building construction projects.

\section{Methodology}

In order to comprehensively investigate economic benefits of implementing prefabricated construction techniques, this research establishes a framework for evaluating multidimensional economic benefits in terms of three aspects, namely, resource-use efficiencies, project progress, and incentive policies.

First, the corresponding models are proposed after determining the economic composition in terms of resource-savings, shortening of construction periods, and latest policy subsidies. Specifically, construction activities and construction machinery that consume different resources, such as water, electricity, and fuel, are identified in order to explore the potential economic benefits from saved resources. On the basis of this idea, prefabricated construction activities from component production to onsite assembling stages and conventional construction activities are fully demonstrated. Various activities with shorter duration are also sorted to identify the economic benefit indicators related to shortening construction periods. Furthermore, since policy subsidies mainly affect capital performance, all cash inflows and outflows during the whole period, including fund raising, land purchase, construction, and building sales, are identified by the study. Policy subsidies, such as financial subsidies, tax incentives, and sales incentives, are analysed to investigate the composition terms of the economic benefits when the latest policy subsidies are adopted.

Second, the results are produced through the BIM-based simulation, in which the same case study is transformed from PRB into TRB. This is because the comparative analysis using two similar but different cases may result in inaccurate evaluation. In addition, BIM platforms based on commonly used commercial software tools are capable of producing relatively reliable data and calculation results.

3.1. Modelling of Resource-Use Efficiencies. As mentioned previously, the economic benefits of PRB projects from the perspective of the resource-use efficiency are mainly derived from cost savings since prefabricated construction can reduce the use of natural resources and energy, such as water, electricity, coal, petrol, and diesel. Compared with the conventional cast-in-situ construction techniques, the prefabricated construction pattern can achieve automated production in factories and adopt on-site assembly procedures. Thus, labour cost can also be significantly decreased by the mechanisation. Figure 1 demonstrates the composition of economic benefits from saved resources through the identification of differences between the conventional and prefabricated construction techniques.

Economic benefits of resource-savings in prefabricated construction can be formulated as

$$
\begin{aligned}
\mathrm{IC}_{r}= & \mathrm{IC}_{r, \mathrm{~A} 1}+\mathrm{IC}_{r, \mathrm{~A} 2}+\mathrm{IC}_{r, \mathrm{~A} 3} \\
= & \left(\mathrm{IC}_{r, \mathrm{~A} 11}+\mathrm{IC}_{r, \mathrm{~A} 12}+\mathrm{IC}_{r, \mathrm{~A} 13}\right) \\
& +\left(\mathrm{IC}_{r, \mathrm{~A} 21}+\mathrm{IC}_{r, \mathrm{~A} 22}+\mathrm{IC}_{r, \mathrm{~A} 23}\right)+\left(\mathrm{IC}_{r, \mathrm{~A} 31}+\mathrm{IC}_{r, \mathrm{~A} 32}\right) \\
= & P_{\mathrm{w}}\left[\alpha_{1} \cdot \mathrm{Q}_{1}+\alpha_{2} \cdot \mathrm{Q}_{2}+\alpha_{3} \cdot S\right]+P_{\mathrm{e}}\left[\left(\beta_{1} \cdot \mathrm{Q}_{\mathrm{Ts}}+\beta_{2} \cdot \Delta \mathrm{Q}_{3}\right)\right. \\
& \left.+\left(\beta_{3} \cdot Q_{\mathrm{Tt}}+\beta_{4} \cdot \Delta \mathrm{Q}_{4}\right)+\beta_{5} \cdot S\right] \\
& +P_{o}\left[\left(\gamma_{1} \cdot Q_{\mathrm{Tm}}+\gamma_{2} \cdot \Delta Q_{5}\right)+\gamma_{3} \cdot S\right],
\end{aligned}
$$

where $\mathrm{IC}_{r}$ represents the economic benefits of resourcesavings; $Q_{1}$ and $Q_{2}\left(\mathrm{~m}^{3}\right)$ denote the engineering quantities of beam-column junctions and prefabricated components, respectively; $S\left(\mathrm{~m}^{2}\right)$ represents the gross floor area; $Q_{\mathrm{Ts}}(t)$ machinery one-shift) denotes the power consumed by electrical machines for steel engineering in the simulated TRB projects; $\Delta Q_{3}(t /$ machinery one-shift $)$ indicates the incremental consumption of machines for steel engineering; $Q_{T t}\left(\mathrm{~m}^{2} / \mathrm{ma}\right.$ chinery one-shift) represents the consumption of machines for the formwork engineering of wall-column junctions in the simulated TRB projects; $\Delta Q_{4}\left(\mathrm{~m}^{2} /\right.$ machinery one-shift $)$ denotes the incremental consumption of machines for the formwork engineering of wall-column junctions; $Q_{\mathrm{Tm}}\left(\mathrm{m}^{3} /\right.$ machinery one-shift) denotes the consumption of machines for the scaffolding engineering in the simulated TRB projects; $\Delta Q_{5}$ $\left(\mathrm{m}^{3} /\right.$ machinery one-shift) represents the incremental consumption of machines for the scaffolding engineering; $P_{\mathrm{w}}, P_{\mathrm{e}}$, and $P_{\mathrm{o}}$ represent the unit prices of water, electricity, and diesel; and $\alpha, \beta$, and $\gamma$ are coefficients.

\subsection{Modelling of Reduced Construction Time. Reducing} construction time without sacrificing quality is beneficial for saving construction project costs, decreasing loan interest payments, and avoiding some finance charges. Thus, shortening construction periods resulting from prefabricated construction can offer several economic benefits. Figure 2 displays the potential economic benefits from the perspectives of capital charges and construction costs, which are used to compare with the conventional cast-in-situ construction technique.

Economic benefits of shorter construction periods caused by adopting prefabricated construction techniques, $\mathrm{IC}_{t}$, can be defined as

$$
\begin{aligned}
\mathrm{IC}_{t}= & \mathrm{IC}_{t, \mathrm{~B} 1}+\mathrm{IC}_{t, \mathrm{~B} 2}+\mathrm{IC}_{t, \mathrm{~B} 3} \\
= & \mathrm{IC}_{t, \mathrm{~B} 1}+\left(\mathrm{IC}_{t, \mathrm{~B} 21}+\mathrm{IC}_{t, \mathrm{~B} 22}\right)+\left(\mathrm{IC}_{t, \mathrm{~B} 31}+\mathrm{IC}_{t, \mathrm{~B} 32}+\mathrm{IC}_{t, \mathrm{~B} 33}\right) \\
= & \sum_{k=1}^{\Delta N} \frac{P_{k} \cdot \Delta N \cdot i_{k}}{\left(1+i_{k}\right)^{\Delta N}}+\sum_{n=1}^{2} \Delta T 1 \cdot P_{m l_{n}}+\sum_{t=1}^{3} \Delta T 2 \times P_{m y_{t}} \\
& +\Delta T 3 \times P_{m y_{c}},
\end{aligned}
$$

where $\Delta N$ represents the reduced number of days for the loan payment; $i_{k}$ and $P_{k}$ indicate the interest rate and total amount of the loan payment, respectively; $\Delta T 1, \Delta T 2$, and $\Delta T 3$ denote the reduced number of days for the construction progress, decoration engineering, and concrete engineering, 


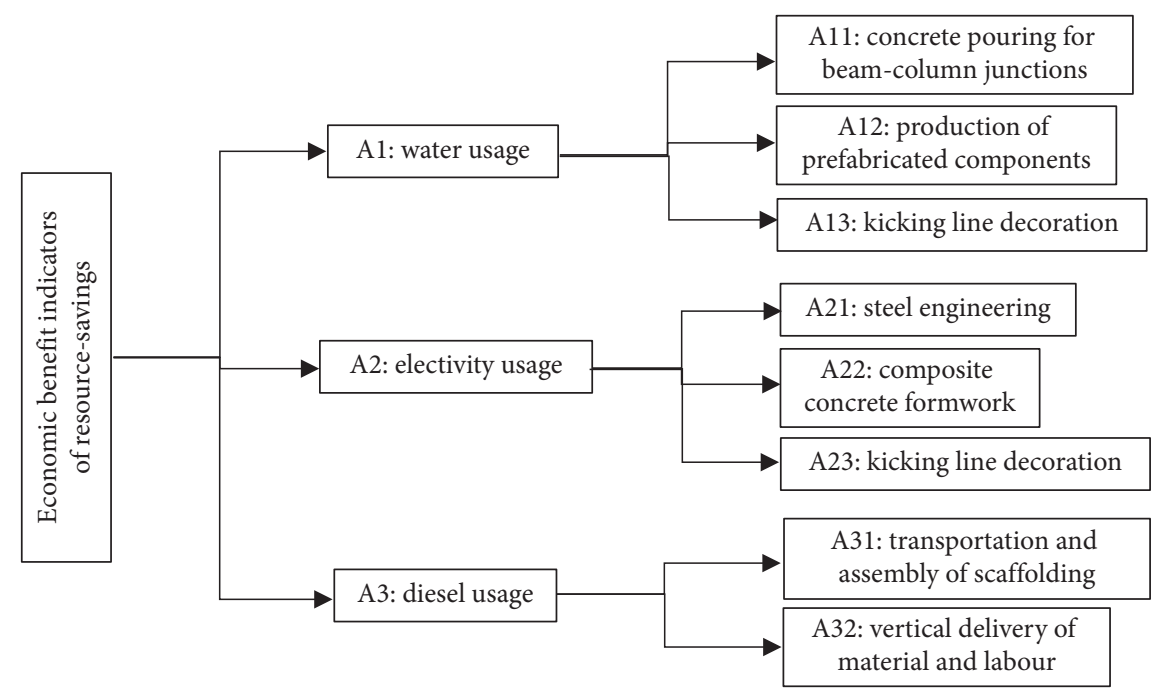

FIGURE 1: Economic benefits of resource-savings in prefabricated construction.

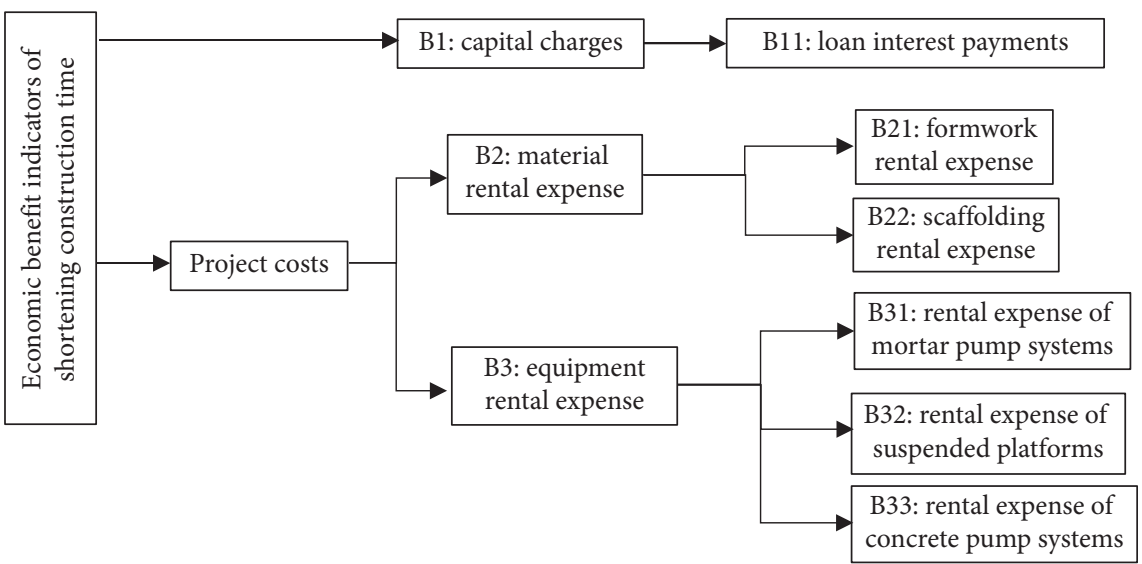

FIGURE 2: Economic benefits of shortening construction time in prefabricated construction.

respectively; and $P_{m l}, P_{m y_{t}}$, and $P_{m y_{c}}$ represent the unit rental price of the $n$th item, such as formwork and scaffolding, the unit rental price of the $t$ th type of equipment, such as mortar pump systems and suspended platforms, and the unit rental price of concrete pump systems, respectively, in $¥ /$ month.

3.3. Modelling of Policy Subsidies. At the early stage of development, local governments often issue several incentive policies, such as financial subsidies and tax incentives, for the adoption and spread of prefabricated construction techniques. These incentive policies not only decrease the PRB project costs and reduce loan payments but also bring more economic returns on invested projects. Various economic factors should be considered, such as the subsidies for the unit price per $\mathrm{m}^{2}$, the proportion for value-added tax exemption, the proportion for enterprise income tax exemption, and the subsidies in terms of floor area ratios (Figure 3).

Economic benefits of policy subsidies caused by adopting prefabricated construction techniques, $\mathrm{IC}_{p}$, can be expressed as equation (3), where a compound interest algorithm is used to calculate the savings in repayments and taxes:

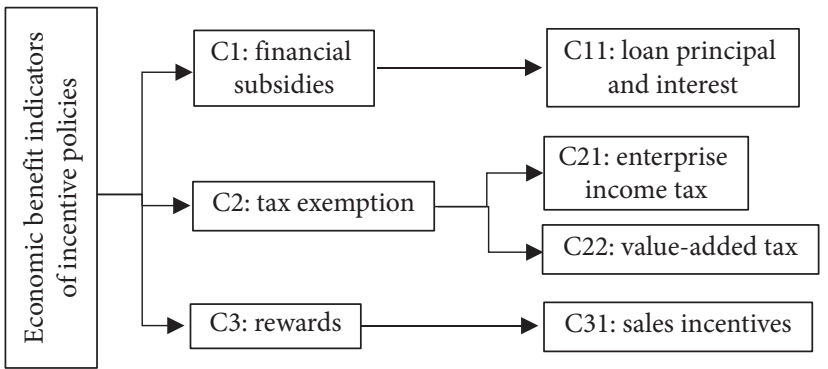

FIGURE 3: Economic benefits of incentive policies in prefabricated construction.

$$
\begin{aligned}
\mathrm{IC}_{p}= & \mathrm{IC}_{p, \mathrm{C} 1}+\mathrm{IC}_{p, \mathrm{C} 2}+\mathrm{IC}_{p, \mathrm{C} 3} \\
= & \mathrm{IC}_{p, \mathrm{C} 11}+\left(\mathrm{IC}_{p, \mathrm{C} 21}+\mathrm{IC}_{p, \mathrm{C} 22}\right)+\mathrm{IC}_{p, \mathrm{C} 31} \\
= & \sum_{k=1}^{N} \frac{S \cdot a \cdot\left(1+i_{k}\right)}{\left(1+i_{k}\right)^{N}}+\left(P_{\mathrm{z}} \cdot J+b \cdot P_{\mathrm{q}}\right) \\
& +c \cdot\left(\frac{S \cdot P_{\mathrm{d}}}{S l}+S \cdot P_{\mathrm{b}}\right),
\end{aligned}
$$


where $S$ and $S l$ represent the floor area and the land area; $i_{k}$ indicates the interest rate for the $k$ th year; $a$ indicates the subsidies for the unit price per $\mathrm{m}^{2} ; N$ denotes the $N$ th repayment period; $J$ denotes the proportion for value-added tax exemption; $P_{\mathrm{z}}$ and $P_{\mathrm{q}}$ represent the expenditures on value-added tax and enterprise income tax, respectively; $P_{\mathrm{d}}$ and $P_{\mathrm{b}}$ represent the unit prices per $\mathrm{m}^{2}$ for land and building; $b$ indicates a proportion of enterprise income tax exemption; and $c$ represents a proportion of a sold floor area, based on which local governments reward the sales of prefabricated buildings.

\section{Background and Data on the Case Study}

4.1. The Selected Case. For the preliminary application of the algorithm proposed in the previous section, an existing apartment building is chosen as a case study to demonstrate the comprehensive economic evaluation, including resourceuse efficiencies, project progress, and incentive policies. The selected project is located in Qingpu District, Shanghai, China. The project can be seen as a representative case as it is applicable to incentive policies issued by the local government. The left image of Figure 4 displays the target building, based on which the BIM model is developed using Autodesk Revit by the researcher, as illustrated in the right image. The Revit BIM platform provides rich data and information on building materials and construction techniques $[38,39]$.

The selected building adopts an assembled integral shear wall structure. The total ground area is $4,015 \mathrm{~m}^{2}$. The main load-bearing prefabricated components include prefabricated laminated panels, prefabricated stairs, prefabricated balconies, and prefabricated exterior walls. Nonload-bearing prefabricated components are prefabricated interior walls and precast concrete facade panels. Figure 5 displays the transformation between the prefabricated construction technique and the cast-in-situ construction technique on the Revit platform. Prefabricated components provide embedded anchors, which are used for crane lifting. Additionally, prefabricated exterior walls often have thicker protective layers than cast-in-situ exterior walls to avoid subsequent decoration engineering. Steel trusses of prefabricated laminated boards aim to reduce steel fixing tasks.

The total duration of this case project was 207 days, from 10 March 2017 to 3 October 2017, and the duration of the main construction phase and decorating phase was 85 and 59 days, respectively. Figure 6 demonstrates the differences between prefabricated and cast-in-situ construction techniques, which are implemented on the Revit platform to simulate their construction processes. The construction project duration changes with the change in the construction process. The resulting simulation is illustrated in the next section.

4.2. Data Preprocessing. Values of variables and coefficients should be determined after the case is selected. The coefficients of equation (1), namely, $\alpha, \beta$, and $\gamma$, are identified based on construction codes, such as Consumption Quota of Prefabricated Construction (TY01-01(01)-2016) [41], Consumption Quota of Building Construction and Decoration
Engineering (TY01-31-2015) [42], and Unified National Consumption Quota of Machinery and Equipment [43]. Table 1 lists the coefficients by analysing primary construction procedures, such as production of prefabricated components, hoisting, concrete pouring, and decoration, and investigating various fees, such as labour, materials, machines, and measures.

Each coefficient of resources-savings for water, electricity, and diesel equals unit resource consumption of the TRB project minus unit resource consumption of the corresponding PRB project. Thus, only the positive coefficients, which refer to the saving parts of PRBs compared with TRBs, are considered. Water savings come from the different construction activities, and the values of $\alpha_{1}, \alpha_{2}$, and $\alpha_{3}$ refer to $\mathrm{Cell}_{2,4}$ of Row 2 and Column 4, Cell $1_{1,4}$, and Cell ${ }_{17,4}$ in Table 1, respectively. Electricity-related and diesel-related savings are derived from the energy consumption of different types of construction machinery and equipment in construction activities. The values of $\beta_{1}$ and $\beta_{2}$ can be determined by summing Rows 6-11 of Column 5 and summing Rows 6-11 of Column 6 , respectively. The values of $\beta_{3}, \beta_{4}$, and $\beta_{5}$ refer to the sum of Rows 12-14 in Column 5, the sum of Rows 13-14 in Column 6 , and Cell $_{17,6} \cdot \gamma_{1}$ is the sum of Cell $_{15,7}$ and Cell $_{15,8}$, and the values of $\gamma_{2}$ and $\gamma_{3}$ come from Cell $_{15,8}$ and $\mathrm{Cell}_{16,8}$, respectively. Furthermore, in this case study, $Q_{1}, Q_{2}, \Delta Q_{3}, \Delta Q_{4}$, $\Delta Q_{5}$, and $S$ are defined as $425.64 \mathrm{~m}^{3}, 750 \mathrm{~m}^{3}, 38.28 \mathrm{t} /$ machinery one-shift, $\quad 643500 \mathrm{~m}^{2} /$ machinery one-shift, $2921.63 \mathrm{~m}^{3} /$ machinery one-shift, and $4015 \mathrm{~m}^{2}$, respectively, according to construction drawings, cost plans, procurement files, and other documents. $Q_{\mathrm{Ts}}, Q_{\mathrm{Tt}}$, and $Q_{\mathrm{Tm}}$ are $674.87 \mathrm{t} /$ machinery one-shift, $56545.02 \mathrm{~m}^{2} /$ machinery one-shift, and $4549.92 \mathrm{~m}^{3} /$ machinery one-shift, respectively, based on the BIM simulation and Codes for Design of Concrete Structures [44]. The unit prices of water, electricity, and diesel $\left(P_{\mathrm{w}}, P_{\mathrm{e}}\right.$, and $P_{o}$ ) are set as $4.57 ¥ / t, 1.86 ¥ / \mathrm{kwh}$, and $6.1 ¥ / \mathrm{L}$, respectively.

It is assumed that the financial resources are mainly derived from the available capital and bank loans. Table 2 lists the detailed information on the project investment and plans. The loan for the first phase, $¥ 1,012,700$, is used for the initial investment. The total investment capital is $¥ 6,000,000$. The investment from the available capital must be more than $20 \%$ of the total investment capital, according to the rules. Thus, the available capital is $¥ 2,988,000$. The loan capital is $¥ 3,012,000$ in terms of the interest rate of $1.85 \%$.

In addition, according to incentive policies issued by local governments in China $[45,46]$, the subsidies for the unit price per $\mathrm{m}^{2}, a$, are set as $¥ 100 / \mathrm{m}^{2}$ in equation (3). The proportion for value-added tax exemption, $J$, is defined as $100 \%$. In addition, there is a proportion of $15 \%$ in the enterprise income tax exemption, namely, $b=0.15$. Local governments reward the sales of prefabricated buildings in terms of $3 \%$ of a sold floor area, namely, $c=0.03$.

\section{Results and Analysis of Simulated Economic Benefits}

\subsection{Specific Performances of Economic Indicators}

5.1.1. Resource-Saving Perspective. The BIM platform is used to simulate these two construction processes. Collected data 


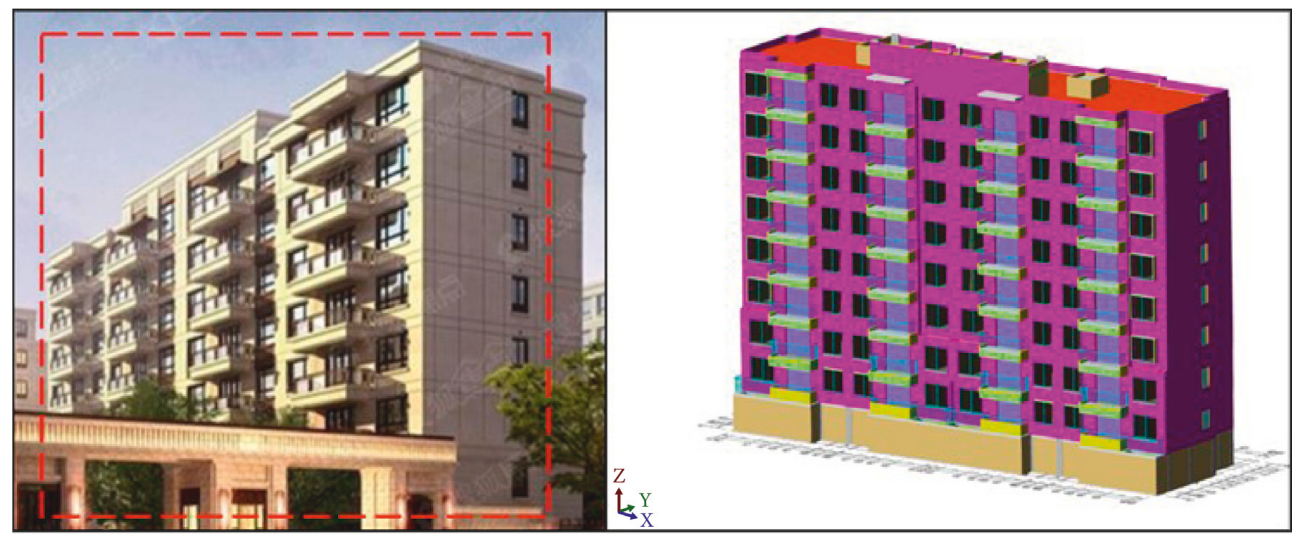

FIGURE 4: Target building provided by the construction company [37] and architectural rendering developed by the researchers.

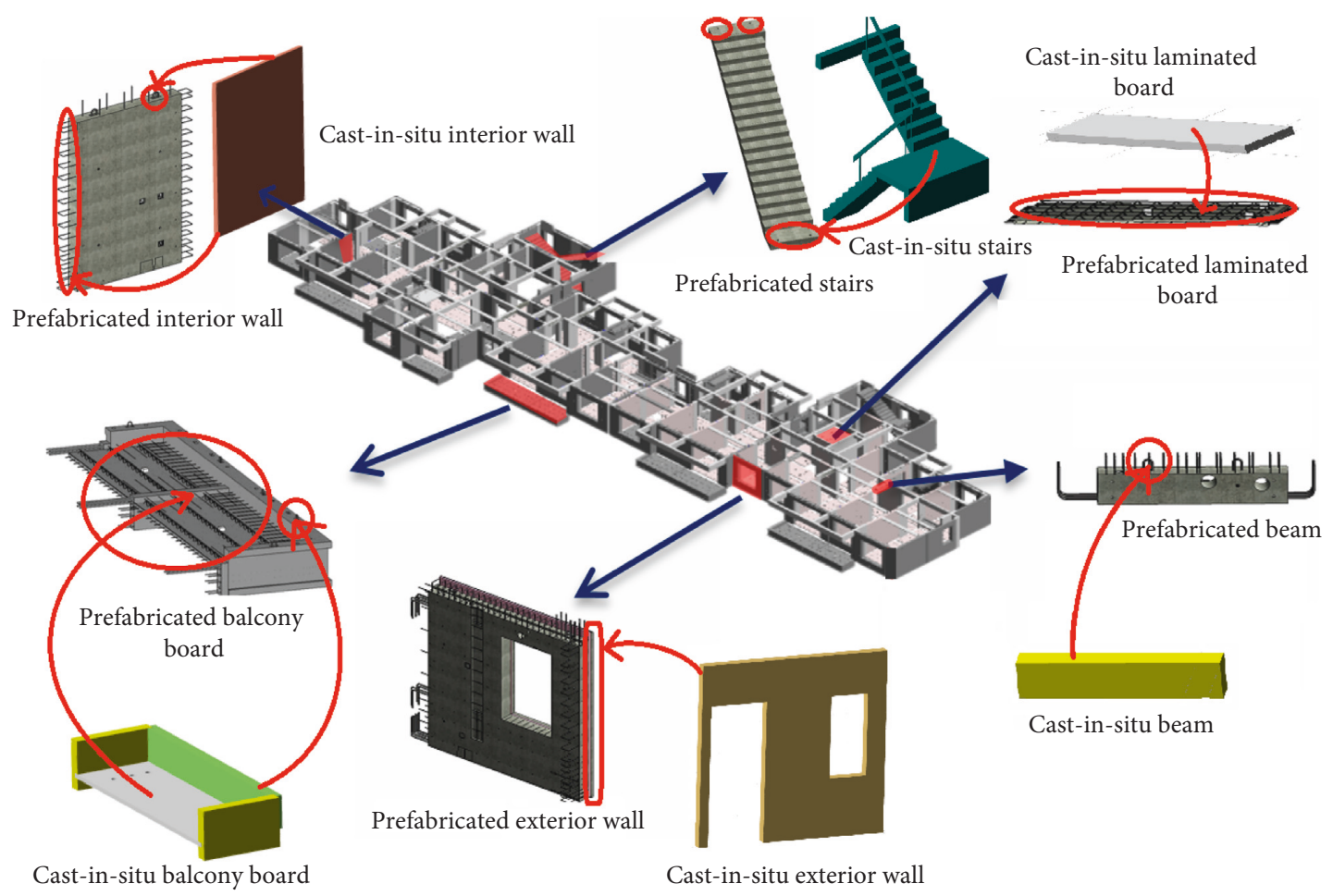

FIGURE 5: Transformation between prefabricated components and cast-in-situ components, developed by the researchers.

on relevant designs and project consumption quantities are then substituted into equation (1) of the economic evaluation. For prefabricated construction, the increments of economic benefits per $\mathrm{m}^{2}$ are summarised in Table 3 by comparison.

By summing all values, it can be concluded that the total economic benefit from resource-savings is $¥ 52.52 / \mathrm{m}^{2}$. The cost savings in water consumption reaches $¥ 17.1 / \mathrm{m}^{2}$ and accounts for $32.6 \%$ of the total reduced cost, as illustrated in Figure 7. Unlike concrete, which is manually cured and vibrated, steam curing of concrete is capable of accurately controlling the usage of water and power in manufacturing factories. Furthermore, water-saving mainly occurs in the three construction activities, namely, concrete pouring of column-beam junctions (A11), production of prefabricated components (A12), and kicking line decoration (A13). These indicators can offer corresponding economic benefits of $¥ 1.005 / \mathrm{m}^{2}, ¥ 0.92 / \mathrm{m}^{2}$, and $¥ 15.2 / \mathrm{m}^{2}$, respectively. Indicator A11 accounts for the proportion of $5.9 \%$, A12 for $5.4 \%$, and A13 for $89.6 \%$ from the water-saving perspective. Furthermore, prefabricated construction produces a saved cost of $¥ 4.3 / \mathrm{m}^{2}$ owing to the electricity-use efficiency, which accounts for $8.2 \%$ of the total reduced cost. Economic merits of $¥ 2.1 / \mathrm{m}^{2}$, $¥ 2.0 / \mathrm{m}^{2}$, and $¥ 0.23 / \mathrm{m}^{2}$ occur in construction activities of steel engineering (A21), composite concrete formwork (A22), and kicking line decoration (A23). In addition, prefabricated construction can save a cost of $¥ 31.1$ / $\mathrm{m}^{2}$ due to the higher utilisation rate of diesel oil. PRB projects often require less fuel-consumption machinery and equipment, such as concrete pump trucks. The economic 


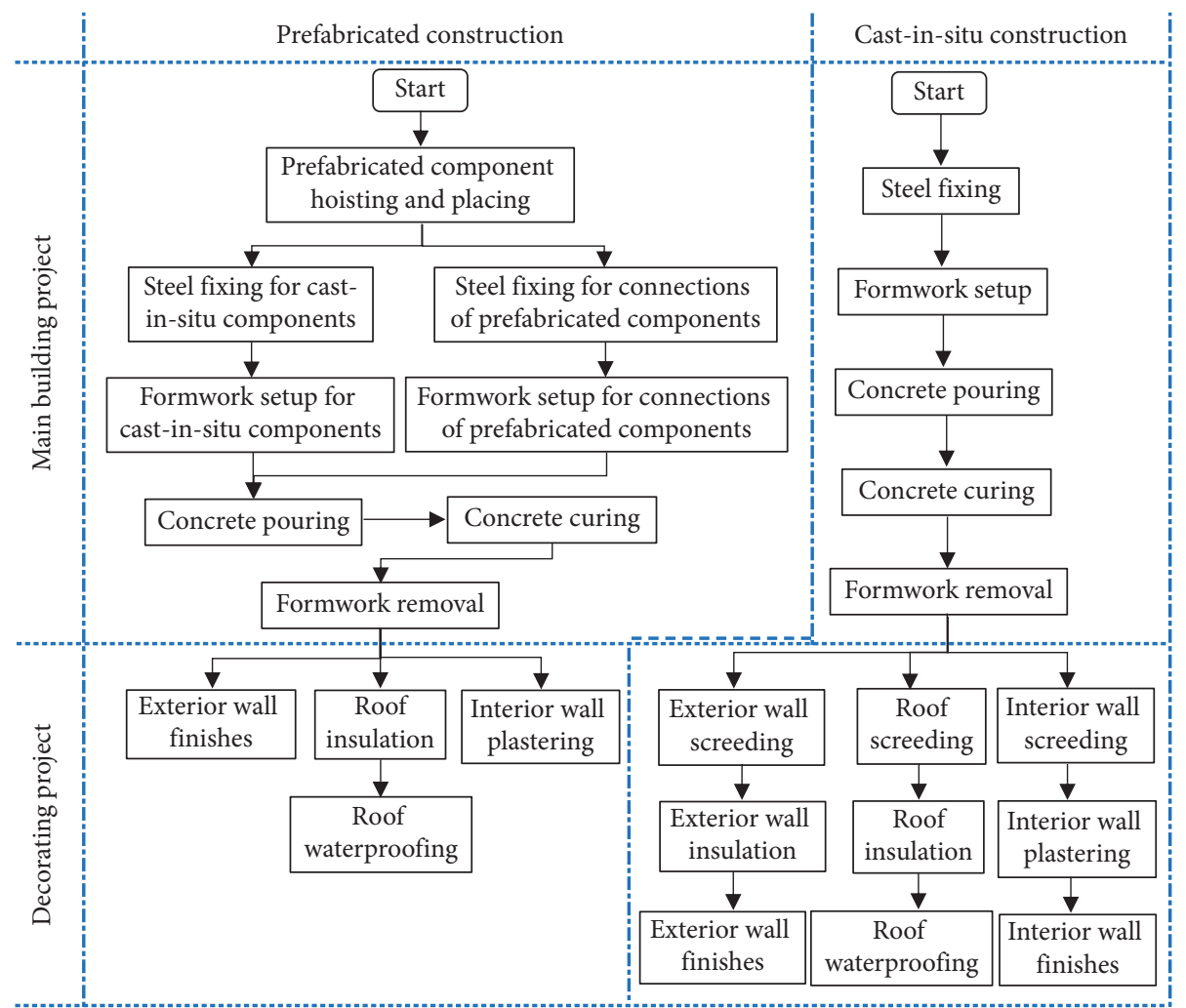

FIGURE 6: Simulated prefabricated and cast-in-situ construction processes developed by the researchers, referring to the construction code $[40]$.

value accounts for $59.2 \%$ of the total reduced cost, consisting of saved costs of $¥ 25.1 / \mathrm{m}^{2}$ in the scaffolding engineering (A31) and $¥ 5.05 / \mathrm{m}^{2}$ in the vertical delivery (A32). Overall, the saved consumption of diesel oil can be considered the most significant contributor from the resource-saving perspective.

5.1.2. Time-Saving Perspective. The number of days for loan repayments, the total repayment, and the construction time are derived from construction management plans and financial reports. Based on the Construction Period Quota of Building Installation Engineering (TY01-89-2016), the repayment days and the construction duration are calculated. These two periods are reduced by 20 and 35 days, respectively. Reducing repayment time is beneficial to save expenses on loan interest payments. Reducing construction time results in the decrease in material rental expenses, such as formwork and scaffolding, and equipment rental expenses, such as pumps and platforms. Table 4 lists the results of economic merits by shortening the construction period.

The total economic benefit by shortening the construction period reaches $¥ 552.9 / \mathrm{m}^{2}$, in which the reduced expense on the loan interest payment (B1) is $¥ 173.3 / \mathrm{m}^{2}$ and accounts for $31.3 \%$ of the total reduced expenses. The benefit from the saved expenses reaches $¥ 379.64 / \mathrm{m}^{2}$, consisting of the material rental (B2) and equipment rental (B3). Indicators B2 and B3 produce the economic merits of $¥ 170.2$ / $\mathrm{m}^{2}(30.8 \%)$ and $¥ 209.5 / \mathrm{m}^{2}(37.9 \%$, ), respectively, as shown in Figure 8 , but there is little difference between their proportions. The B2-related economic value is mainly derived from the saved expenses on the formwork rental (B21) and the scaffolding rental (B22). B21 and B22 account for $46.2 \%$ and $53.9 \%$ of B2, respectively. In addition, adopting prefabricated construction can save expenses of $¥ 43.1 / \mathrm{m}^{2}$ in the rental of mortar pump systems (B31), $¥ 28.9 / \mathrm{m}^{2}$ in the rental of suspended platforms (B32), and $¥ 137.5 / \mathrm{m}^{2}$ in the rental of concrete pump systems (B33). B31, B32, and B33 account for $20.6 \%, 13.8 \%$, and $65.6 \%$ of $\mathrm{B} 3$, respectively.

5.1.3. Policy Perspective. Table 5 provides the results of economic merits due to the transformation from the prefabricated construction technique to the conventional castin-situ.

Specifically, the total economic benefit by adopting the latest incentive policies reaches $¥ 155.63 / \mathrm{m}^{2}$. The reduced expense on the principal and interest $(\mathrm{C} 11)$ is $¥ 8.9 / \mathrm{m}^{2}$ because of financial subsidies (C1). It accounts for $5.7 \%$ of the total economic benefit, as shown in Figure 9. In addition, it should be noted that the tax exemption (C2) is only available to prefabricated building projects, which are checked and identified by local governments in terms of building area, assembly rate, structural characteristic, and construction technology in China. Other sustainable construction projects, such as green buildings, are only stimulated by means of financial subsidies. As for the selected case, the benefit from the tax exemption (C2) reaches $¥ 66.4 / \mathrm{m}^{2}$, consisting of the enterprise income tax exemption (C21) and value-added 


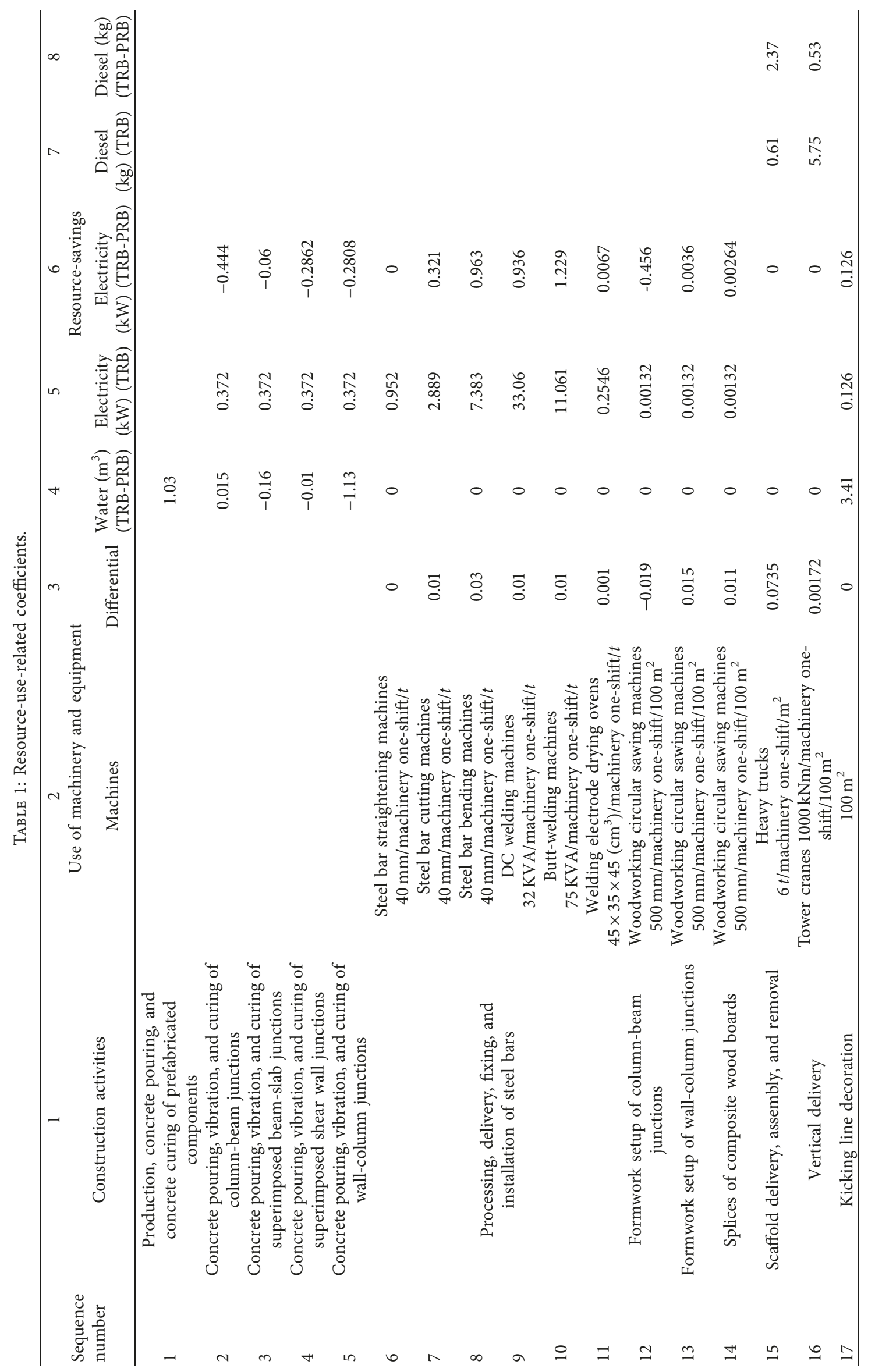


TABLE 2: Project financing and investment plans.

\begin{tabular}{|c|c|c|c|c|c|}
\hline \multirow[b]{2}{*}{ Item } & \multirow{2}{*}{$\begin{array}{l}\text { Capital } \\
(¥ 1000)\end{array}$} & \multicolumn{4}{|c|}{ Project progress ( $¥ 1000$ ) } \\
\hline & & $\begin{array}{c}\text { Phase } \\
1\end{array}$ & $\begin{array}{c}\text { Phase } \\
2\end{array}$ & $\begin{array}{c}\text { Phase } \\
3\end{array}$ & $\begin{array}{c}\text { Phase } \\
4\end{array}$ \\
\hline $\begin{array}{l}\text { Construction } \\
\text { investments }\end{array}$ & $5,891.4$ & $1,777.4$ & $1,692.9$ & $1,514.4$ & 906.4 \\
\hline Loan interest & 108.9 & 32.9 & 31.3 & 28.0 & \\
\hline Total investment & 6,000 & $1,810.2$ & $1,724.3$ & $1,542.4$ & 906.4 \\
\hline Available capital & 2,988 & 1,896 & 660 & 432 & \\
\hline Loan & 3,012 & $1,012.7$ & 1,056 & 943.3 & \\
\hline $\begin{array}{l}\text { Project } \\
\text { financing }\end{array}$ & 6,000 & $2,908.7$ & 1,716 & $1,375.3$ & \\
\hline
\end{tabular}

TABLE 3: Results of economic merits brought by resource-savings $\left(¥ / \mathrm{m}^{2}\right)$.

\begin{tabular}{lccccc}
\hline & Water & Power & Diesel & Sum & Total \\
\hline $\begin{array}{l}\text { Concrete pouring of } \\
\text { column-beam junctions } \\
\text { (A11) }\end{array}$ & 1.005 & - & - & & \\
$\begin{array}{l}\text { Production of prefabricated } \\
\text { components (A12) }\end{array}$ & 0.92 & - & - & 17.1 & \\
$\begin{array}{l}\text { Kicking line decoration } \\
\text { (A13) }\end{array}$ & 15.2 & - & - & & \\
$\begin{array}{l}\text { Steel engineering (A21) } \\
\text { Formwork engineering of } \\
\text { column-beam junctions }\end{array}$ & - & 2.1 & - & & 52.5 \\
$\begin{array}{l}\text { (A22) } \\
\text { Kicking line decoration } \\
\text { (A23) }\end{array}$ & - & 2.0 & - & 4.3 & \\
$\begin{array}{l}\text { Scaffolding engineering } \\
\text { (A31) }\end{array}$ & - & - & 25.1 & & \\
$\begin{array}{l}\text { Vertical delivery } \\
\text { engineering (A32) }\end{array}$ & - & - & 5.05 & & \\
\hline
\end{tabular}

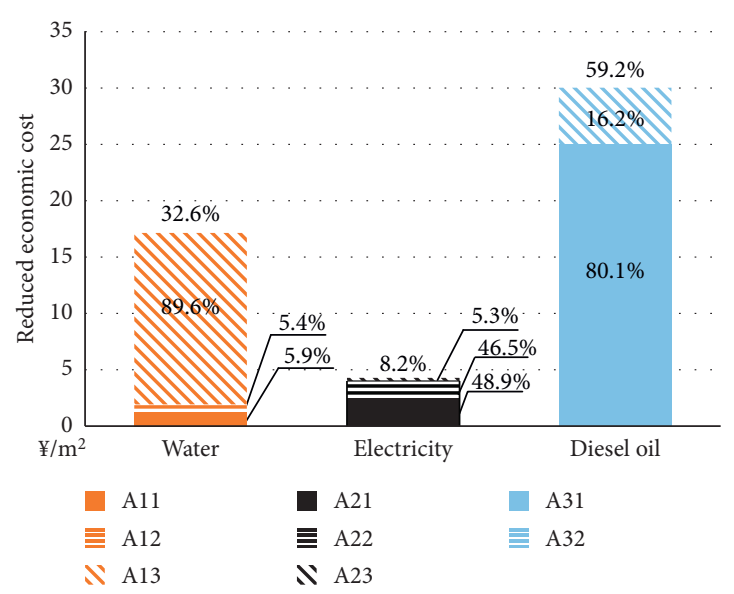

FIGURE 7: Economic proportions of indicators from resourcesaving perspective.

tax exemption (C22). These two factors, C21 and C22, offer the economic merits of $¥ 23.9 / \mathrm{m}^{2}$ and $¥ 42.4 / \mathrm{m}^{2}$, respectively, accounting for $36 \%$ and $64 \%$ in $\mathrm{C} 2$. The local government rewards investors in terms of sold floor areas of $\mathrm{PRB}$ projects. Thus, the sales incentives (C31) increase by $¥ 80.4 / \mathrm{m}^{2}$,
TABLE 4: Results of economic merits by shortening construction period $\left(¥ / \mathrm{m}^{2}\right)$.

\begin{tabular}{lcccc}
\hline & Item & $\begin{array}{c}\text { Cost- } \\
\text { saving }\end{array}$ & Sum & Total \\
\hline $\begin{array}{l}\text { Capital charges } \\
\text { (B1) }\end{array}$ & Loan interest payments & 173.3 & 173.3 & \\
$\begin{array}{l}\text { Material rental } \\
\text { expense (B2) }\end{array}$ & $\begin{array}{c}\text { Formwork (B21) } \\
\text { Scaffolding (B22) }\end{array}$ & 78.5 & 170.2 & \\
& $\begin{array}{c}\text { Mortar pump systems } \\
\text { (B31) }\end{array}$ & 43.1 & & 552.9 \\
$\begin{array}{l}\text { Equipment rental } \\
\text { expense (B3) }\end{array}$ & $\begin{array}{c}\text { Suspended platforms } \\
\text { (B32) }\end{array}$ & 28.9 & 209.5 & \\
& $\begin{array}{c}\text { Concrete pump } \\
\text { systems (B33) }\end{array}$ & 137.5 & & \\
\hline
\end{tabular}

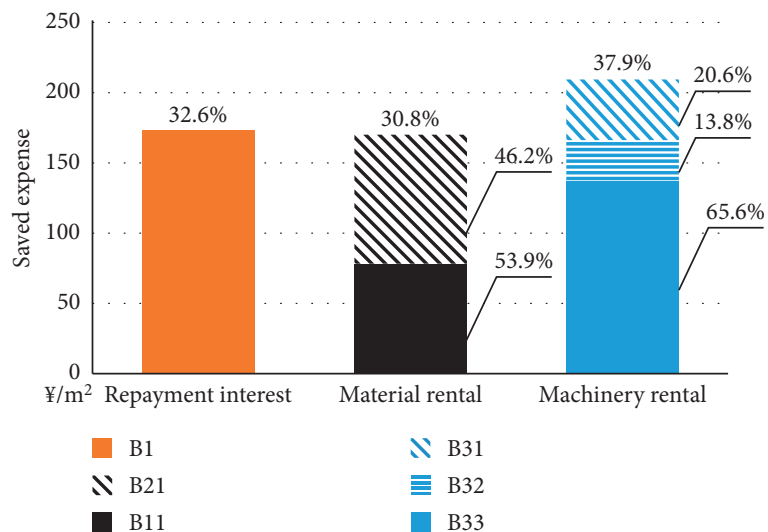

Figure 8: Economic proportions of indicators from time-saving perspective.

TABLE 5: Results of economic merits by adopting incentive policies $\left(¥ / \mathrm{m}^{2}\right)$.

\begin{tabular}{lcccc}
\hline & Item & $\begin{array}{c}\text { Obtained } \\
\text { benefits }\end{array}$ & Sum & Total \\
\hline $\begin{array}{l}\text { Financial } \\
\text { subsidies (C1) }\end{array}$ & $\begin{array}{c}\text { Loan principal and } \\
\text { interest (C11) } \\
\text { Enterprise income } \\
\text { tax (C21) }\end{array}$ & 8.9 & 8.9 & \\
$\begin{array}{l}\text { Tax exemption } \\
(\mathrm{C} 2)\end{array}$ & $\begin{array}{c}\text { Value-added tax } \\
\text { (C22) }\end{array}$ & 42.4 & 66.4 & 155.63 \\
Rewards (C3) & Sales incentives (C31) & 80.4 & 80.4 & \\
\hline
\end{tabular}

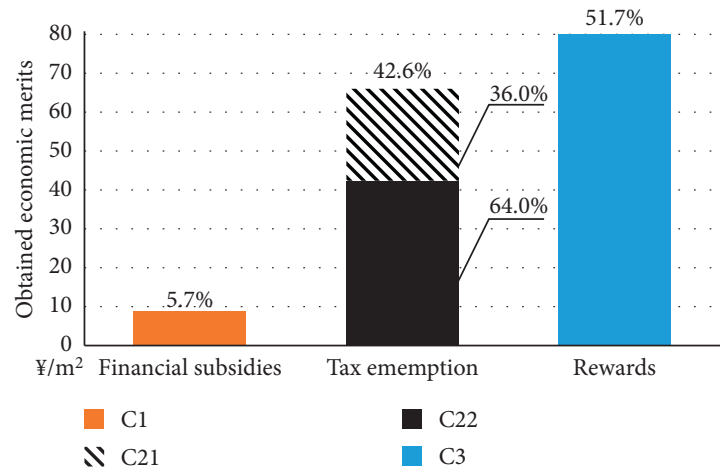

FIGURE 9: Economic proportions of indicators from policy perspective. 
which accounts for $51.7 \%$ of the total economic benefit by adopting the latest incentive policies of prefabricated construction.

5.2. Overall Performances of Economic Benefits. Previous research suggested that the increased cost can reach between $¥ 464.41 / \mathrm{m}^{2}$ and $¥ 783.94 / \mathrm{m}^{2}$ when adopting prefabricated construction in China $[47,48]$. However, the present research considers that the comprehensive economic merit can reach $¥ 739.6 / \mathrm{m}^{2}$ through higher resource-use efficiencies, faster project progress, and current incentive policies for the adoption of prefabricated construction. The proposed economic benefit is capable of offsetting the incremental cost and even producing revenues. In addition, the comprehensive incremental benefit and its economic components are not directly affected by the size of the site. As discussed in Section 3, the benefit evaluation of saving resources mainly relies on materials and other resources consumed by machines. The benefit evaluation of shortening construction time is determined by the project progress, and the benefit evaluation of receiving policy subsides is related to building size and application situation of prefabricated construction technologies. However, comprehensive economic benefit of a PRB project is often positively correlated with its scale. Increasing the project scale is capable of promoting the economic benefit. For example, from the resource-saving perspective, a larger floor area means that more building components are fabricated and more construction materials, such as formwork, are reused in manufacturing factories. A larger floor area also means that more building components, such as exterior walls, are prefabricated, and thus, the on-site construction progress can be more significantly accelerated. Equation (3) also indicates that the subsidies and rewords are related to the project scale. In this case, the economic benefit from shortening the construction period can be regarded as the most significant contributor, namely, ¥552.9/ $\mathrm{m}^{2}$, accounting for $74.8 \%$ of the comprehensive economic evaluation. The current incentive policies contribute the smallest value of the comprehensive economic evaluation, namely, $¥ 52.3 / \mathrm{m}^{2}$, which accounts for $7.1 \%$.

In order to further identify the temporal change of the comprehensive economic benefit in the project, the economic benefits of saving resources, shortening construction time, and receiving policy subsides with the construction period are calculated for main construction days in terms of equations (1)-(3). The results are listed in Table 6 and plotted in Figure 10 to display the temporal changes in economic benefits over a project period.

The building project progress can be divided into three phases, namely, construction phase, decoration phase, and sales phase. After the construction and decoration phases, there are no economic benefits caused by resource- or timesavings. Yet, the comprehensive economic merit will be increased to $¥ 739.6 / \mathrm{m}^{2}$ owing to sales incentives. For this building project, the duration of the construction phase is from Day 1 to Day 85 and the decoration phase is from Day 85 to Day 207. Figure 10 demonstrates that the comprehensive incremental benefit has significant growth between Day 1 and Day 110.
TABLE 6: Economic benefit values on main days in the project.

\begin{tabular}{lcccc}
\hline \multirow{2}{*}{$\begin{array}{l}\text { Construction } \\
\text { period (day) }\end{array}$} & $\begin{array}{c}\text { Economic benefits } \\
\text { Raving }\end{array}$ ( $\left.\mathrm{m}^{2}\right)$ \\
\hline 1 & 2.03 & 21.37 & 50.50 & 73.90 \\
10 & 4.06 & 42.74 & 52.60 & 99.40 \\
20 & 6.09 & 64.11 & 56.90 & 127.10 \\
29 & 12.12 & 85.48 & 62.30 & 159.90 \\
39 & 15.15 & 106.85 & 63.10 & 185.10 \\
52 & 17.18 & 128.22 & 64.20 & 209.60 \\
61 & 22.21 & 149.59 & 65.20 & 237.00 \\
71 & 25.24 & 170.96 & 66.40 & 262.60 \\
74 & 29.27 & 192.33 & 66.70 & 288.30 \\
79 & 34.30 & 213.70 & 67.80 & 315.80 \\
85 & 38.33 & 235.07 & 69.40 & 342.80 \\
92 & 41.36 & 256.44 & 70.90 & 368.70 \\
103 & 42.69 & 297.81 & 71.00 & 411.50 \\
115 & 43.42 & 332.18 & 72.40 & 448.00 \\
124 & 44.75 & 343.55 & 73.10 & 461.40 \\
135 & 45.48 & 361.92 & 74.60 & 482.00 \\
143 & 46.51 & 392.29 & 75.30 & 514.10 \\
157 & 47.54 & 425.66 & 76.10 & 549.30 \\
164 & 48.57 & 463.03 & 77.20 & 588.80 \\
179 & 49.60 & 497.40 & 78.10 & 625.10 \\
189 & 51.62 & 521.77 & 79.20 & 652.60 \\
207 & 52.65 & 552.95 & 80.10 & 685.71 \\
237 & 52.65 & 552.95 & 89.00 & 694.61 \\
266 & 52.65 & 552.95 & 95.00 & 700.61 \\
267 & 52.52 & 552.95 & 133.00 & 738.48 \\
\hline & & & & \\
\hline
\end{tabular}

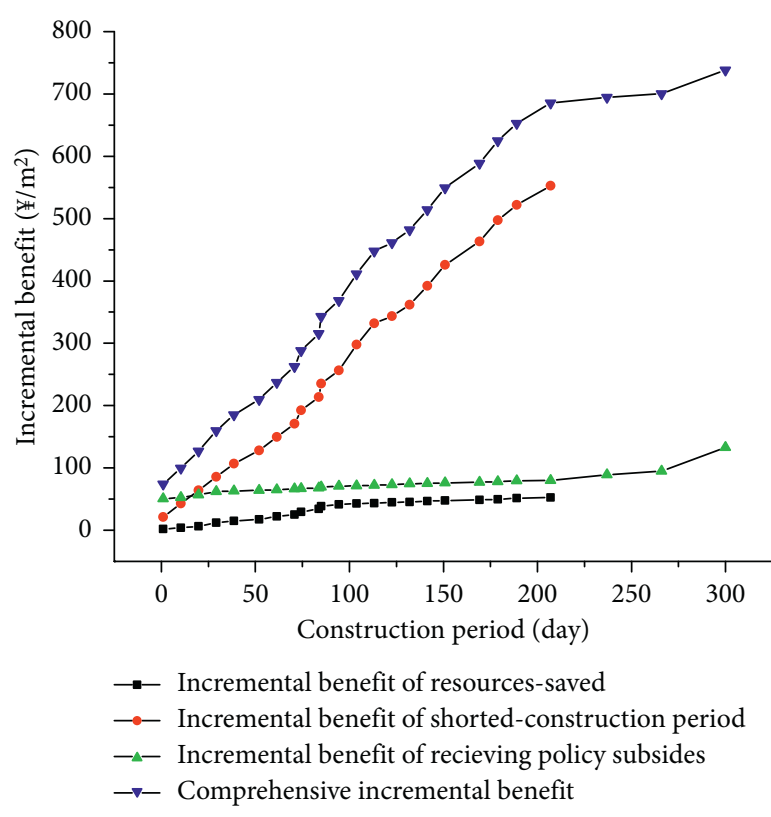

Figure 10: Changes in economic benefits over a project period.

The trend line in the incremental benefit of shorting construction time aims to plot the cumulative economic merits on main days brought by the prefabricated construction technique from the time-saving perspective. It can be observed that there is a rapid increase in the economic merit due to the faster on-site construction progress when selecting the prefabricated construction technique. Its trend 
change is similar with the line of the comprehensive incremental benefit, and its economic values are greater than other economic components after around Day 20. This means that the time-saving factor can be considered the largest contributor to the economic benefit of the prefabricated construction technique, expect for the early stage of the building project. The fastest growth occurs between Day 90 and Day 207, which means that decoration engineering is more important to incremental values produced by the faster construction progress of the prefabricated construction technique. This is because production of prefabricated components simplifies the on-site work of exterior walls, slabs, and other building parts. High-quality prefabricated components with insulation layers can avoid a number of decoration tasks involving plastering and insulation and reduce the rental expenses on material and equipment.

Furthermore, saving resources has been the lowest contributor to the comprehensive economic benefit over the project period. It experiences a relatively fast growth between Day 25 and Day 85 and a slow increase from Day 85 to Day 207. Compared to the decoration phase, the construction phase can offer more economic benefits due to resource-use efficiencies of prefabricated construction. As for the incremental benefit brought by policy subsidies of prefabricated construction, its relatively fast growth occurs during the early stage of building construction; yet, sales incentives will contribute to the growth of economic benefit caused by policy subsidies after the decoration phase.

\section{Conclusions}

Overall, prefabricated construction has been considered a widely accepted alternative to conventional cast-in-situ concrete construction since it is capable of offering numerous benefits for investors and contractors. However, researchers hold various viewpoints on economic merits of PRB projects. Thus, considering availability and selection of the construction techniques, the economic analysis of PRB projects, should be conducted for projecting the potential expenditure and indicating their economic benefits. This research aims to comprehensively evaluate the economic benefits of implementing prefabricated construction techniques in order to surpass the economic barrier and promote the development of PRBs in China. The comprehensive economic evaluation is formulated in terms of resource-use efficiencies, project progress, and incentive policies. An apartment building in Shanghai is selected as a case study. Construction progress is simulated on the BIM platform when the same case study is rationally transformed from the prefabricated to the conventional cast-in-situ construction technique. For the adoption of prefabricated construction, the significant economic benefit results from saved resources, shortened construction periods, and policy subsidies.

The results reveal that the comprehensive economic merit can reach $¥ 739.6 / \mathrm{m}^{2}$ when selecting the prefabricated construction process. The economic benefit offered by shortening the construction period can be regarded as the most significant contributor because of a large proportion.
Among the project-progress-related factors, the reduced expenses on machinery rental and material rental are seen as the largest and smallest parts, respectively, but there is not a significant difference. The reward policy plays the most important role from the policy perspective. It can offer an economic benefit of $80.4 / \mathrm{m}^{2}$ and account for more than half of the total policy-related economic benefit.

Additionally, the assessment measure can be beneficial for decision makers to consider prefabricated construction techniques in building construction projects in terms of the potential economic benefits. The results can contribute to judicious construction patterns and the efficient utilisation of incentive policies. This research is expected to contribute to further improvement by incorporating more detailed data on construction processes and addressing more economic indicators in future research.

\section{Data Availability}

The data used to support the findings of this study are available from the corresponding author upon request.

\section{Conflicts of Interest}

The authors declare that they have no conflicts of interest.

\section{Acknowledgments}

The authors are thankful for the support from the National Key R\&D Program of China (2016YFC0701810 in 2016YFC0701800), North China University of Technology Science and Technology Innovation Project (18XN149), and North China University of Technology Yu Jie Talent Development Program (18XN154).

\section{References}

[1] J. Hong, G. Q. Shen, Z. Li, B. Zhang, and W. Zhang, "Barriers to promoting prefabricated construction in China: a costbenefit analysis," Journal of Cleaner Production, vol. 172, pp. 649-660, 2018.

[2] D. Yeoh and M. Fragiacomo, "The design of a semiprefabricated LVL-concrete composite floor," Advances in Civil Engineering, vol. 2012, Article ID 626592, 19 pages, 2012.

[3] R. E. Smit, Off-Site Construction Implementation Resource: Off-Site and Modular Construction Explained, Off-Site Construction Council, National Institute of Building Sciences, 2014, http://www.wbdg.org/resources/site-andmodular-construction-explained.

[4] R. Y. Zhong, Y. Peng, F. Xue et al., "Prefabricated construction enabled by the Internet-of-Things," Automation in Construction, vol. 76, pp. 59-70, 2017.

[5] S. Mostafa, N. Chileshe, and T. Abdelhamid, "Lean and agile integration within offsite construction using discrete event simulation," Construction Innovation, vol. 16, no. 4, pp. 483-525, 2016.

[6] M. Arashpour, Y. Bai, G. Aranda-mena, A. Bab-Hadiashar, R. Hosseini, and P. Kalutara, "Optimizing decisions in advanced manufacturing of prefabricated products: theorizing supply chain configurations in off-site construction," Automation in Construction, vol. 84, pp. 146-153, 2017. 
[7] S. J. Kolo, F. P. Rahimian, and J. S. Goulding, "Offsite manufacturing construction: a big opportunity for housing delivery in Nigeria," Procedia Engineering, vol. 85, pp. 319327, 2014.

[8] V. W. Y. Tam, I. W. H. Fung, M. C. P. Sing, and S. O. Ogunlana, "Best practice of prefabrication implementation in the Hong Kong public and private sectors," Journal of Cleaner Production, vol. 109, pp. 216-231, 2015.

[9] Z. Li, G. Q. Shen, and X. Xue, "Critical review of the research on the management of prefabricated construction," Habitat International, vol. 43, pp. 240-249, 2014.

[10] N. Blismas, C. Pasquire, and A. Gibb, "Benefit evaluation for off-site production in construction," Construction Management and Economics, vol. 24, no. 2, pp. 121-130, 2006.

[11] M. M. Fard, S. A. Terouhid, C. J. Kibert, and H. Hakim, "Safety concerns related to modular/prefabricated building construction," International Journal of Injury Control and Safety Promotion, vol. 24, no. 1, pp. 10-23, 2017.

[12] E. M. Generalova, V. P. Generalov, and A. A. Kuznetsova, "Modular buildings in modern construction," Procedia Engineering, vol. 153, pp. 167-172, 2016.

[13] E. D. L. Franks, Safety and Health in Prefabricated Construction: A New Framework for Analysis, University of Washington, Seattle, WA, USA, 2018.

[14] B.-G. Hwang, M. Shan, and K.-Y. Looi, "Knowledge-based decision support system for prefabricated prefinished volumetric construction," Automation in Construction, vol. 94, pp. 168-178, 2018.

[15] D. Matic, J. R. Calzada, M. S. Todorovic, M. Erić, and M. Babin, "Chapter 16-cost-effective energy refurbishment of prefabricated buildings in Serbia," in Cost-Effective Energy Efficient Building Retrofitting, F. Pacheco-Torgal, C.-G. Granqvist, B. P. Jelle, G. P. Vanoli, N. Bianco, and J. Kurnitski, Eds., pp. 455-487, Woodhead Publishing, Cambridge, UK, 2017.

[16] R. Minunno, T. O'Grady, G. Morrison, R. Gruner, and M. Colling, "Strategies for applying the circular economy to prefabricated buildings," Buildings, vol. 8, no. 9, p. 125, 2018.

[17] O. Pons, "18-assessing the sustainability of prefabricated buildings," in Eco-Efficient Construction and Building Materials, F. Pacheco-Torgal, L. F. Cabeza, J. Labrincha, and A. de Magalhães, Eds., pp. 434-456, Woodhead Publishing, Cambridge, UK, 2014.

[18] N. Vieira, M. Amado, and F. Pinho, "Prefabricated solution to modular construction in Cape Verde," AIP Conference Proceedings, vol. 184, no. 1, article 020071, 2017.

[19] Y. Chang, X. Li, E. Masanet, L. Zhang, Z. Huang, and R. Ries, "Unlocking the green opportunity for prefabricated buildings and construction in China," Resources, Conservation and Recycling, vol. 139, pp. 259-261, 2018.

[20] The state council, "Guiding opinions of the general office of the State Council on vigorously developing prefabricated buildings," 2016, http://www.gov.cn/zhengce/content/201609/30/content_5114118.htm.

[21] A. E. Fenner, M. Razkenari, H. Hakim, and C. J. Kibert, "A review of prefabrication benefits for sustainable and resilient coastal areas," in Proceedings of the 6th International Network of Tropical Architecture Conference, Tropical Storms as a Setting for Adaptive Development and Architecture, University of Florida, Gainesville, FL, USA, December 2017.

[22] L. Jaillon and C. S. Poon, "Life cycle design and prefabrication in buildings: a review and case studies in Hong Kong," $A u$ tomation in Construction, vol. 39, pp. 195-202, 2014.

[23] C. Mao, F. Xie, L. Hou, P. Wu, J. Wang, and X. Wang, "Cost analysis for sustainable off-site construction based on a multiple-case study in China," Habitat International, vol. 57, pp. 215-222, 2016.

[24] J. Jeong, T. Hong, C. Ji et al., "An integrated evaluation of productivity, cost and CO 2 emission between prefabricated and conventional columns," Journal of Cleaner Production, vol. 142, pp. 2393-2406, 2017.

[25] M. Afzal, S. Maqsood, and S. Yousaf, "Performance evaluation of cost saving towards sustainability in traditional construction using prefabrication technique," International Journal of Research in Engineering and Science, vol. 5, no. 5, pp. 73-79, 2017.

[26] S. Jang and G. Lee, "Process, productivity, and economic analyses of BIM-based multi-trade prefabrication-A case study," Automation in Construction, vol. 89, pp. 86-98, 2018.

[27] E. I. Antillón, M. R. Morris, and W. Gregor, "A value-based cost-benefit analysis of prefabrication processes in the healthcare sector: a case study," in Proceedings of the 22nd International Group for Lean Construction Conference, Oslo, Norway, June 2014.

[28] N. Blismas and R. Wakefield, "Drivers, constraints and the future of offsite manufacture in Australia," Construction Innovation, vol. 9, no. 1, pp. 72-83, 2009.

[29] H. Xue, S. Zhang, Y. Su, and Z. Wu, "Capital cost optimization for prefabrication: a factor analysis evaluation model," Sustainability, vol. 10, no. 1, p. 159, 2018.

[30] C. Z. Li, F. Xue, X. Li, J. Hong, and G. Q. Shen, “An Internet of Things-enabled BIM platform for on-site assembly services in prefabricated construction," Automation in Construction, vol. 89, pp. 146-161, 2018.

[31] M. O. Fadeyi, "The role of building information modeling (BIM) in delivering the sustainable building value," International Journal of Sustainable Built Environment, vol. 6, no. 2, pp. 711-722, 2017.

[32] S. Song, J. Yang, and N. Kim, "Development of a BIM-based structural framework optimization and simulation system for building construction," Computers in Industry, vol. 63, no. 9, pp. 895-912, 2012.

[33] J. Zhang, Y. Long, S. Lv, and Y. Xiang, "BIM-enabled modular and industrialized construction in China," Procedia Engineering, vol. 145, pp. 1456-1461, 2016.

[34] J. Lee and J. Kim, "BIM-based 4D simulation to improve module manufacturing productivity for sustainable building projects," Sustainability, vol. 9, no. 3, p. 426, 2017.

[35] G. S. Baltasi and R. Akbas, "Structured evaluation of preconstruction cost alternatives with bim and resource integrated simulation," in Proceedings of the Lean and Computing in Construction Congress-Joint Conference on Computing in Construction, pp. 499-506, Heraklion, Greece, July 2017.

[36] S. Mostafa, K. P. Kim, V. W. Y. Tam, and P. Rahnamayiezekavat, "Exploring the status, benefits, barriers and opportunities of using BIM for advancing prefabrication practice," International Journal of Construction Management, pp. 1-11, 2018.

[37] Longxin Group, 2019, http://www.lxgroup.cn/.

[38] Autodesk, "Revit built for building information modeling," 2019, https://www.autodesk.com/products/revit/overview.

[39] M. Hu, "BIM-enabled pedagogy approach: using BIM as an instructional tool in technology courses," Journal of Professional Issues in Engineering Education and Practice, vol. 145, no. 1, article 05018017, 2019.

[40] The Ministry of Housing and Urban-Rural Development, Code for Construction of Concrete Structures (GB 50666-2011), China Architecture \& Building Press, Beijing, China, 2012. 
[41] The Ministry of Housing and Urban-Rural Development, Consumption Quota of Prefabricated Construction (TY0101(01)-2016), China Planning Press, Beijing, China, 2017.

[42] The Ministry of Housing and Urban-Rural Development, Consumption Quota of Building Construction and Decoration Engineering (TY01-31-2015), China Planning Press, Beijing, China, 2015.

[43] Housing and Urban-Rural Development Institute of Standards and Norms, Unified National Consumption Quota of Machinery and Equipment, China Planning Press, Beijing, China, 2012.

[44] The Ministry of Housing and Urban-Rural Development, Code for Design of Concrete Structures (GB 50010-2010), China Architecture \& Building Press, Beijing, China, 2015.

[45] Shanghai Municipal Development and Reform Commission, Demonstration Projects of Special Support Measures on Building Energy Efficiency and Green Buildings, Shanghai Municipal Development and Reform Commission, Shanghai, China, 2016.

[46] The General Office of the Municipal People's Government of Beijing, Implementation Opinions on Accelerating the Development of Prefabricated Buildings, The General Office of the Municipal People's Government of Beijing, Beijing, China, 2017.

[47] M. Ningning and C. Bingqing, "Analysis on the cost control of prefabricated concrete buildings," Journal of Fujian University of Technology, vol. 15, no. 4, pp. 399-403, 2017.

[48] L. Lihong, G. Bohui, Q. Baoku, L. Yunxia, and L. Lan, "Empirical analysis on the cost of prefabricated construction contrast with cast-in-place building," Construction Economy, vol. 9, pp. 102-105, 2013. 


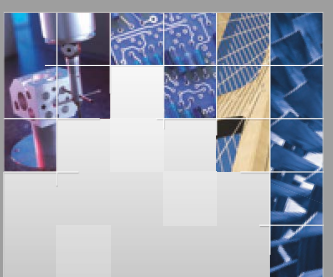

\section{Enfincering}
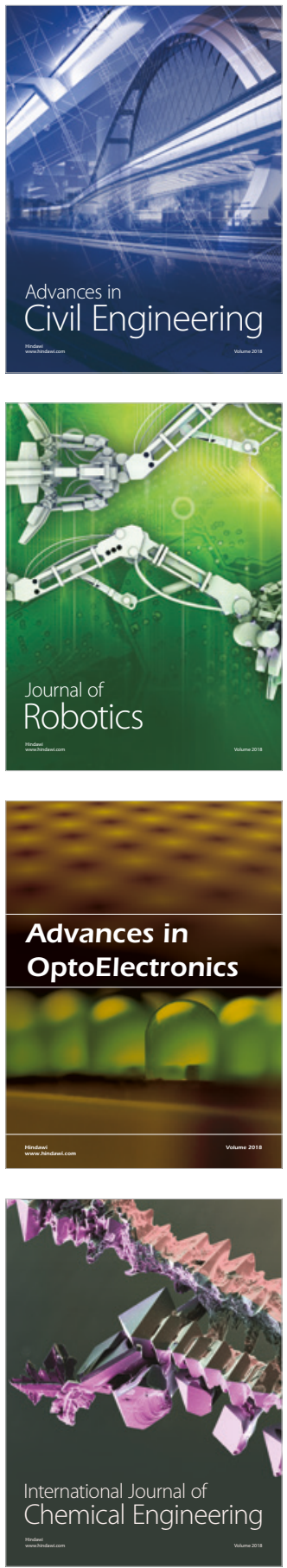

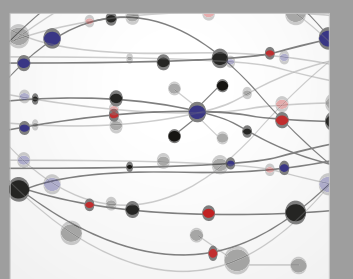

\section{Rotating \\ Machinery}

The Scientific World Journal

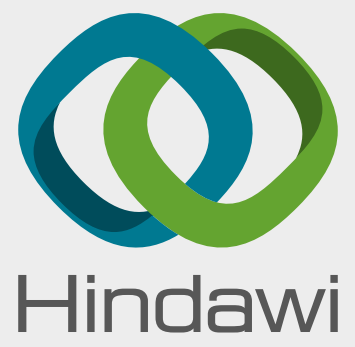

Submit your manuscripts at

www.hindawi.com
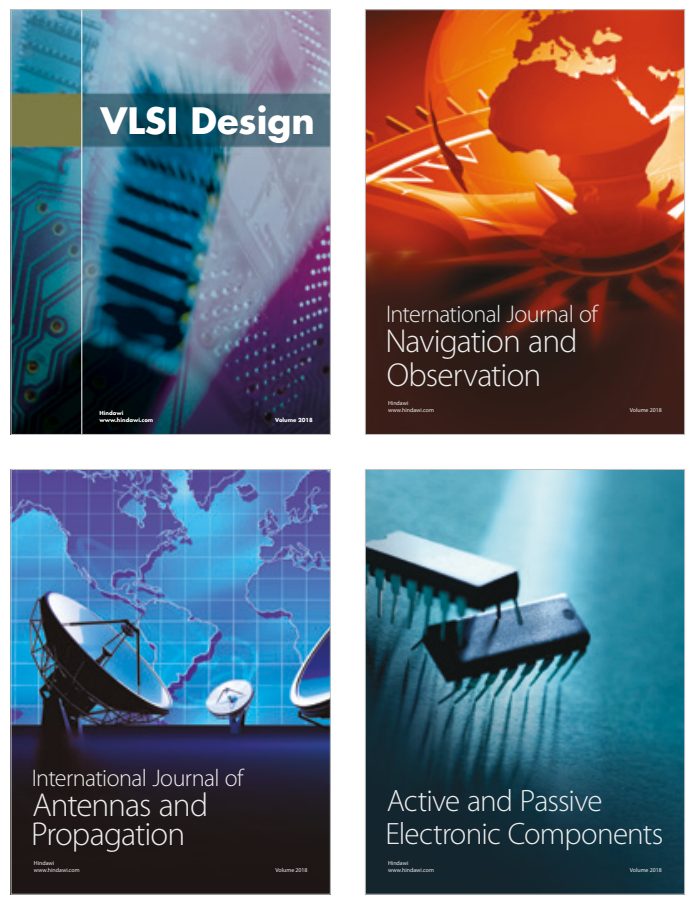
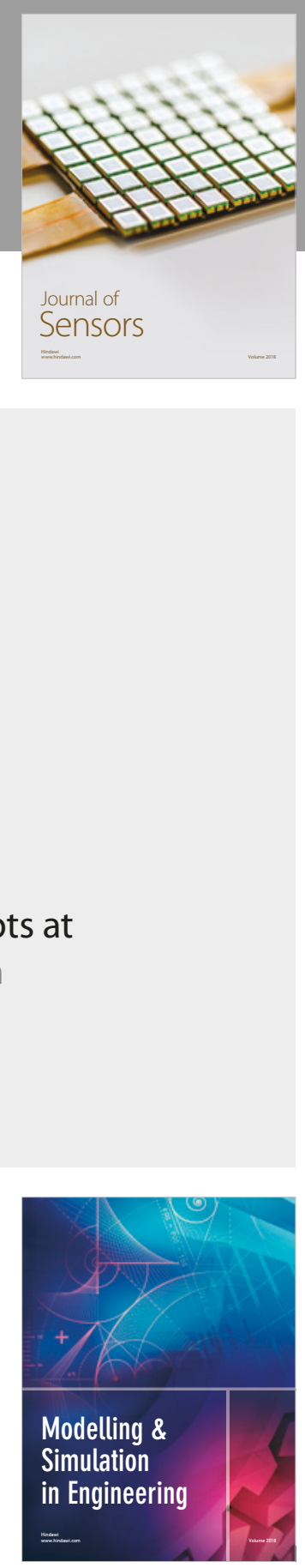

\section{Advances \\ Multimedia}
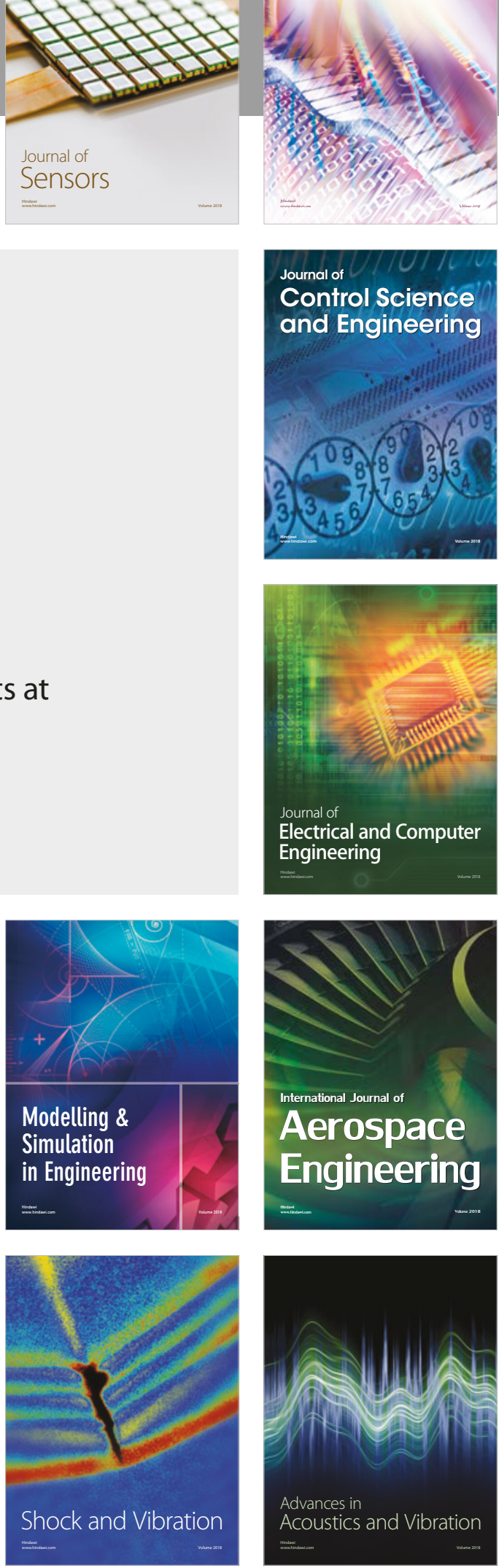